\title{
Membumikan Spirit Toleransi Sunan Kudus Kepada Generasi Millenial Melalui Tali Akrab
}

Kholidia Efining Mutiara, ${ }^{\mathrm{a}, 1,{ }^{*}}$, Nur Said ${ }^{\mathrm{b}, 2}$

anstitut Agama Islam Negeri Kudus, Jawa Tengah, 59311, Indonesia

${ }^{b}$ Institut Agama Islam Negeri Kudus, Jawa Tengah, 59311, Indonesia

${ }^{1}$ kholidiaeveningmutiara19@gmail.com*; ${ }^{2}$ nursaid@stainkudus.ac.id ${ }^{*}$

ARTICLE INFO

Article history:

Received : 2019-02-05

Revised : 2019-04-14

Accepted : 2019-12-20

Keywords:

Grounding

Millennial Generation

Sunan Kudus

Kata Kunci:

Membumikan

Generasi Millenial

Sunan Kudus

\section{ABSTRACT}

Intolerance, violence, riots, terror to religious leaders, hoax news, expressions of hatred, provocative issues, in the name of religion are sources of animosity between people and groups. This triggers national dimensions such as in Indonesia and even the world. Therefore this research focuses on national studies, which seeks to earthing the spirit of tolerance of teachings through the struggle of Sunan Kudus, which is implemented to the millennial generation, through interfaith communities and beliefs (Tali Akrab). This study uses phenomenological approach and content analysis by collecting data through observation, interviews and documentation from 2014 to 2018. The findings revealed that there was a the strengthening of tolerance value of Sunan Kudus era, which can be applied to Millennials through (Tali Akrab), where this activity can produce one of the efforts to strengthen religious tolerance.

\section{ABSTRAK}

Intoleransi, kekerasan, kerusuhan, teror pada pemuka agama, berita hoax, ujaran kebencian, isu provokatif, dengan mengatasnamakan agama menjadi sumber permusuhan baik antar umat dan golongan. Hal inilah yang terjadi dimensi nasional seperti di Indonesia bahkan dunia. Maka dalam penelitian ini lebih focus pada kajian nasional yaitu berupaya untuk membumikan spirit toleransi ajaran melalui perjuangan sunan Kudus yang diimplementasikan kepada generasi millenial, melalui komunitas lintas agama dan kepercayaan (Tali Akrab). Penelitian ini menggunakan pendektan fenomenologis dan content analysis dengan melakukan pengumpulan data melalui observasi, wawancara dan dokumentasi, dimana data diperoleh dari tahun 2014-2018. Temuan dalam penelitian ini adalah adanya penguatan nilai toleransi era sunan Kudus yang bisa diaplikasikan kepada generasi Millenial melalui tali akrab, dimana langkah ini dapat menghasilkan salah satu upaya penguatan toleransi beragama.

\section{Pendahuluan}

Kilas balik mengingat tragedi wilayah Sudan selatan memisahkan diri dengan Sudan pada tahun 2011 penyebabnya adalah perbedaan agama dan keyakinan. Ketika Sudan telah misahkan diri dan menjadi Negara mandiri, bukan damai yang terjadi tapi konflik terjadi lagi yang dipicu faktor kesukuan.(17) Berbagai kerusuhan dengan mengatas namakan agama sebagai sumber permusuhan antar umat, seperti halnya beberapa waktu lalu, dunia diributkan dengan keberadaan radikalisme dan terorisme dengan alibi kepentingan agama. Islam dan jihad seakan menjadi kambing hitam yang menjadikan perbincangan yang tiada usai berbagai forum. Kasus Ambon dan Maluku yang menelan ribuan korban jiwa, dimana hal itu mencerminkan terjadinya konflik sosial antar agama dan suku secara berhimpitan. Hal ini seperti halnya sebuah penelitian menyampaikan bahwa perlakuan intoleransi kekerasan dan diskriminasi pada kelompok minoritas.(2)

Kekerasan demi kekerasan bergulir silih berganti, yang bermula dari persoalan konflik vertical namun kemudian merembet ke persoalan horizontal, konflik ini terwujud dalam bentuk konflik antar etnis dan antar agama. Di poso, Sulawesi Tengah, Konflik yang dimulai dari perkelahian antar warga 
berubah menjadi konflik antar komunitas agama Islam dan Kristen.(8)

Beralih pada tahun ini, sering sekali ujaran kebencian dan hoax menjadi topik hangat, karena keberadaannya dapat dikatakan sebagai tindakan pecah belah, sebab objeknya adalah SARA (Suku, Agama, Ras dan Antargolongan). Kita tentu sudah tahu bahwa ujaran kebencian bisa disebut juga sebagai isu profokatif dimana unsur kebencian terdapat di dalamnya. Hoax sama artinya dengan berita bohong yang mengandung Unsur Provokatif juga. Pertanyaan yang akan muncul adalah, mengapa hal tersebut terjadi untuk suatu motif tertentu? Jawabannya adalah satu, yakni lemahnya sikap toleransi kita pada perbedaan khususnya dalam konteks agama dan kepercayaan. Berikut data-data yang peneliti kumpulkan terkait ujaran kebencian dan berita hoax yang beredar saat ini khususnya dalam hal agama dan kepercayaan.

Serangan dan teror pada kiai dan para pemuka agama yang terjadi pada beberapa waktu lalu seakan menjadi sebuah teror yang mencemaskan. Masih teringat betul seorang pemuda yang menyerang umat gereja di Sleman dengan bersenjatakan Parang. Biksu Mulyanto di Tangerang tepatnya daerah Leguk juga mengalami nasib serupa saat melangsungkan Ibadah. Tidak berhenti di situ, Keluarga Kiai di Pesantren Al Falah Kediri juga cukup menyeret kecemasan meskipun tidak ada korban jiwa. Kabar terbaru, Kiai Umar Basyri disergap orang tak dikenal saat melangsungkan Ibadah Salat Subuh, alasannya sampai saat ini belum cukup jelas, tetapi bedasarkan analisis pribadi, bisa dipastikan semua itu terjadi karena tidak ada toleransi antar umat beragama dan di picu oleh Ujaran Kebencian sebelumnya. Kemudian di Situbondo Jawa Timur terjadi pula kerusuhan yang diakibatkan dari menghina Islam dan Kiai.

Ujaran Kebencian isu SARA (Suku, Agama, Ras dan Antargolongan) juga dimanfaatkan untuk kepentingan politik. Hal ini penulis analisis pula berasal dari tidak adanya nilai toleransi khususnya dalam agama, dampaknya hal ini malah disalah gunakan untuk kepentingan politik menjelang pilkada.

Wahid Institute dan lembaga Survei Indonesia juga merilis mengenai 10 kelompok yang sering menjadi sasaran ujaran kebencian dari masyarakat bahkan sering pula diartikulasikan berupa kekerasan fisik. Sasarannya antara lain ; LGBT (26,1\%), Komunis $(16,1 \%)$, Yahudi $(10,7 \%)$, Kristen $(2,2 \%)$, Wahabi $(0,5 \%)$, Katolik $(0,4 \%)$ dan Konghucu $(0,1 \%)$. Survei tersebut apabila digambarkan terdapat $59,9 \%$ responden memiliki minimal suatu kelompok yang di benci. Lalu 92,2\% tidak setuju jika yang menjadi pemuka pemerintah bukan dari golongan mereka sendiri, dan $82,4 \%$ dapat di deskripsikan mereka tidak rela jika anggota kelompok yang dibenci menjadi tetangga mereka.

Menjelang pilkada 2018, SARA merupakan alat politik yang berpotensi kuat meningkatkan sikap intoleransi dan menebalkan sikap konservatisme beragama dikalangan masyarakat. Sebagaimana data yang dipaparkan oleh Kompas.com setidaknya terdapat 201 kejadian pelanggaran terhadap kebebasan beragama. Posisi daerah yang tingkat pelanggarannya paling tinggi adalah Jawa Barat, setidaknya terdapat 29 kejadian, 26 kejadian di Jakarta, 14 kejadian di Jawa Tengah, 12 kejadian di Jawa timur, dan 12 kejadian di Banten. Naiknya intoleransi yang di picu dari Kontestasi Politik ini, setidaknya perlu adanya kombinasi antara penegakan hukum dan dialog antar umat beragama untuk mengantisipasi provokasi yang mempengaruhi masyarakat dimana secara sistematis mereka memproduksi kebohongan (hoax) dengan menggunakan sentimen SARA.

Berkiblat pada kasus-kasus intoleransi, perlu bagi kita memiliki solusi lain sebagai pijakan atau wadah untuk melakukan perubahan. Setidaknya kita telah mengetahui, bahwa Islam Moderat dapat menjadi penengah kedamaian pada dunia ini. Mengingat banyak sekali jalur ekstrim kanan dan kiri yang mengharuskan kita mampu di tengah-tengah antara dua jalur ekstrim.(5) Oleh karena itu perlu bagi kita untuk dapat berada diantara keduanya. Salah satu langkah untuk menjadi Islam Moderat adalah dengan memiliki sikap Toleransi Beragama. Islam Moderat merupakan Islam dengan mengusung genre perdamaian, yakni mengambil jalan tengah, karena sejatinya tidak ingin terlibat perselisihan, sebab moderat bukanlah paradigma yang condong 
pada salah satu kubu ekstrim. Pemilihan jalan tengah ini tidak boleh dipahami sebagai sikap toleran pada semua perbedaan, bahkan sikap apatis lalu membiarkan pertarungan antar 2 kubu yang berlangsung tanpa ada usaha untuk menyelesaikan perseteruan tersebut. Sebab kita tau bahwa sikap toleransi terdapat 2 macam, yakni pasif dan aktif. Jika passif kita cukup toleransi untuk diri kita sendiri, tetapi jika aktif maka kita perlu mengamalkan untuk kegiatan sosial.(13)

Sebenarnya, Toleransi beragama bukanlah hal yang baru, nabi Muhammad SAW telah mengajarkannya di beberapa abad silam, dan di tanah jawa, sosok Syaikh Ja'far Shodiq atau sering dipanggil Sunan Kudus juga telah mengajarkan hal ini pada masyarakat Kudus. Sunan Kudus yang telah membawa sebuah akulturasi budaya untuk kedamaian warga Kudus yang majemuk keberagamaannya waktu itu. Dari latar belakang tersebut, bukanlah hal yang tidak mungkin jika kita dapat menghidupkan lagi spirit toleransi Sunan Kudus untuk kita aplikasikan saat ini.

Melalui sebuah wadah atau komunitas yang mampu menampung seluruh agama, suku dan kepercayaan, bukanlah hal yang mustahil jika perlahan sikap toleransi beragama akan mengakar pada tiap individu. Wadah tersebut merupakan komunitas lintas Agama, salah satunya pada Komunitas lintas Agama di Pantura yakni "Tali Akrab". Kini kita telah mengetahui bahwa toleransi beragama telah lama dicanangkan, akan tetapi mengapa hingga saat ini masih ada konflik dengan melandaskan agama dan kepercayaan sebagai sumber konflik dan alasan untuk melangsungkan tindakan Radikalisme?

Tulisan ini juga menjawab sebuah permasalahan yang diangkat Rosyid yang menyatakan bahwa Local Wisdom yang diwariskan oleh Sunan Kudus (Pelarangan menyembelih sapi). Yang secara realistik tak terbukti dengan fakta yang dituliskan bahwa konflik antar umat beragama secara terbuka dan terselubung marak terjadi, Rosyid berpandangan demikian sebab faktor penyebab pergeseran makna toleransi beragama (Pantang Penyembelihan Sapi) di Kudus merupakan akibat dari santri yang terdidik pada pendidikan formal, generasi muda yang menegakkan secara utuh Alqur'an Hadis serta ketidaktahuan masyarakat Kudus yang hidup kini menyatakan pamali menyembelih sapi. Faktor diataslah yang menjadi alasan pergeseran makna toleransi keberagamaan. Sehingga dapat disimpulkan bahwa local wisdom yang dibawakan Sunan Kudus khususnya pada pelarangan penyembelihan sapi kurang begitu berperan penting dalam menciptakan kedamaian keberagamaan.(18) Demi menghindari luasnya kajian, maka tulisan ini akan difokuskan pada membumikan spirit Toleransi Sunan Kudus kepeda generasi millenial melalui tali akrab, berikut fokus masalah pada tulisan ini: Pertama, apa saja nilai-nilai toleransi warisan Sunan Kudus? Kedua, Bagaimana peran tali akrab dalam membumikan Toleransi?

\section{Tinjauan Pustaka}

\section{Makna Toleransi Beragama}

Kata 'toleransi' bermakna sikap atau sifat toleran. Modal dasar memupuk sikap toleransi antarsesama dalam kehidupan sosial.(17) Toleransi beragama yang dianut seseorang tidak seharusnya dipaksakan untuk diikuti, akan tetapi kebebasan berkeyakinan adalah hak setiap individu.(13)

Agama merupakan pegangan utama dalam melangsungkan kehidupan, karena pegangan utama inilah setiap individu memang seharusnya memegang teguh agama tersebut untuk kelangsungan hidupnya atau dalam istilah lain adalah Fantisme, yang tentunya berimbas pada dirinya Sendiri, akan tetapi bukan berarti kita memegang teguh keyakinan yang kita miliki kemudian mengaggap agama lain adalah salah atau sesat. Apabila kita mengacu kepada konteks Fanatisme beragama hal tersebut benar, akan tetapi apabila yang kita hadapi adalah konteks toleransi beragama, tentu hal tersebut tidaklah benar. Hal ini sama dengan yang disampaikan Thodorson dan theodorson dalam bukunya, bahwa agama itu, bersifat sungguh-sungguh pribadi dan sungguhsungguh sosial.(11)

Manusia hidup tentu membutuhkan orang lain atau dalam istilah lain Zoon Politicon oleh karena itu sikap toleransi harus ada pada tiap individu, apalagi soal keyakinan, dimana setiap orang berhak menentukan apa keyakinannya, tidak perlu bagi kita untuk menyalahkan keyakinan yang dianut orang tersebut.

Apabila kita pahami, faktor pemicu konflik antar dan intern umat beragama, 
Pertama, berupa pemahaman yang dangkal, fanatik, dan tekstual terhadap ajaran agamanya, berdampak memandang sempit pemeluk agama lain. Kedua, adanya loko penggerak untuk menyelesaikan probem perbedaan antar agama dengan konflik. Ketiga, konflik sebagai pelampiasan atas keterbatasan penuhi kebutuhan hidup bagi pelaku karena faktor sumber hidup, kemiskinan, dan disharmoni sosial. Interaksi sosial positif tercipta bila harmoni sosial dan empati sosial tercipta juga terantisipasi sikap agresif.(11)

\section{Generasi Millenial}

Generasi millennial merupakan generasi yang lahir pada tahun 1980-2000, dalam konteks ini merupakan pemuda. Tetapi secara spesifik tahun kelahiran atara 1982-2000 dapat pula disebut generasi Y sebab mereka lahir setelah generasi $\mathrm{X}$ yakni generasi yang lahir pada tahun 1960-1980 an. Ada pula sebutan lain untuk generasi millenial, yakni generasi paterpan dan generasi boomerang. Adapun ciri yang terdapat pada masyrakat millennial, diantaranya; berpendidikan tinggi, tidak buta teknologi, pelaku enterpreauner, memiliki cita-cita yang besar, peduli pada orang lain, berorientasi pada hasil, bukan orang agamis, dapat mengerjakan berbagai tugas, berani mengambil resiko, gencar mencari kesempatan bisnis, dan memiliki rasa penasaran yang tinggi. Generasi milenial merupakan generasi yang spesial, karena generasi ini tidak buta teknologi(16) Sehingga dapat kita simpulkan terdapat dua alasan untuk sebutan tersebut untuk generasi millennial, yakni; Pertama, merugikan dan membahayakan diri sendiri, sebab generasi ini cenderung melawan perintah orang tua yang disebabkan hal ekonomi atau gaya hidup. Kedua, kecenderungan untuk menunda dan menerobos fase-fase remaja, seperti menikah, memulai karier dsb.

Pada penelitian ini terdapat kesamaan dan perbedaan pada penelitian Mukhlis. Penelitian Mukhlis terdapat beberapa kesamaan dengan penelitian penulis, yakni; penelitian mengarah pada terciptanya kerukunan umat beragama, toleransi umat beragama. Tidak hanya berhenti pada persamaan penelitian, pada penelitian dalam tulisan ini dan penelitian Mukhlis terdapat pula beberapa perbedaan, diataranya;
Pada penelitian Mukhlis, kerukunan umat beragama dapat dipersatukan jika kita memahami dan dapat mengaplikasikan teologi umat beragama.(10) Sedangkan pada tulisan ini, toleransi beragama dapat muncul dengan kita dapat berdiri di tengah perbedaan, yakni dengan menghidupkan kembali spirit toleransi Sunan Kudus melalui Komunitas Lintas Agama di Pantura yakni Tali Akrab.

Selanjutnya pada penelitian Mukhlis, Objek penelitian adalah Pancasila sebagai teologi kerukunan umat beragama, sedangkan dalam tulisan ini, Objek penelitian adalah Ajaran Toleransi Beragama Ala sunan Kudus yang dikemas melalui Komunitas Lintas Agama di Pantura yakni Tali Akrab.

\section{Metode Penelitian}

Tulisan ini merupakan produk kualitatif dengan pendekatan fenomenologi. Pendekatan fenomenologi merupakan sebuah pendakatan pada studi agama yang dihadirkan untuk mempelajari hakikat agama secara gamblang. Dalam memahami fenomena agama, pendekatan ini membutuhkan keterbukaan dan empati, oleh krena itu perlu hubungan erat antara peneliti dan objek yang di teliti.(7) Pendekatan ini disampaikan dengan tujuan mengembangkan data-data sosial, dan data-data ini merujuk pada data primer.(20)

Pada pendekatan fenomenologis lebih menekankan kesubjektifan perilaku masyarakat, dengan cara memasuki langsung dunia konseptual dari subjek penelitian, sehingga mengerti apa dan bagaimana suatu penelitian dapat berkembang pada peristiwa dalam kehidupan sehari-hari.(9) Selain itu data yang disajikan dalam bentuk verbal dan bukan bentuk angka, karena penelitian yang digunakan adalah kualitatif.(3)

Dalam proses penelitian ini menggunakan observasi partisipatoris. Observasi partisipatoris yakni peneliti ikut serta terjun langsung dalam pengamatan, bukan sekedar pengamatan jarak jauh. Melalui observasi partisipatoris kegiatan yang terjadi tentu amat jelas untuk peneliti amati. Selain itu moment pada komunitas yang peneliti amati tidak hanya sekali, melainkan beberapa kali yakni sejak tahun 2014 hingga tahun 2018. Selain observasi, peneliti juga menggunakan wawancara dan 
dokumentasi baik berupa buku, catatan, maupun laporan hasil penelitian dari peneliti terdahulu sebagai sumber penelitian.

Metode analisa digunakan untuk menganalisa data-data yang berhasil di kumpulkan. Metode analisa data merupakan suatu langkah yang sangat kritis dalam penelitian, peneliti harus memastikan pola mana yang akan digunakan, apakah pola statistik atau non statistik. Dalam hal ini penulis menggunakan analisis non statistik, artinya data yang ada di analisis menurut isinya, karena itu analisis semacam ini di sebut analisis isi.(15)

\section{Hasil dan Diskusi}

\section{a. Nilai-Nilai Toleransi Warisan Sunan Kudus}

Penyebaran Islam dengan tindakan akulturasi budaya (memadukan dua budaya tanpa menghilangkan sifat asli pada budaya tersebut) antara budaya dalam Agama Islam dengan Budaya Agama Hindu-Budha. Tindakan tersebut adalah salah satu strategi Sunan Kudus untuk mendakwahkan Islam, yakni menyebarkan agama Islam melalui jalur Hindu-Budha (dalam hal kebudayaan). Disebutkan dalam penelitian Mustaqim bahwa proses Internalisasi atau membumikan ajaran agama tentu membutuhkan wahana. Wahana yang mampu melakukan tugas tersebut tak lain adalah pendidikan untuk memasukkan ajaran Islam pada nusantara. Hal ini tentu tidak mudah maka pada saat itu Walisongo menggunakan pendekatan dakwah yang lebih akulturatif di dalamnya terdapat tradisi dan budaya lokal. Inilah Walisongo yang mampu memikat hati masyarakat tanpa menghapus warisan tradisi lokal, Sunan Kudus merupakan salah satunya dalam menjalankan akulturasi budaya sebagai sarana dakwah dan toleransi.(12)

Berikut nilai-nilai Toleransi warisan Sunan Kudus, antara lain:

\section{Bukti Historis dan Folklor}

Syaikh Ja'far Shodiq dalam menyiarkan Agamanya melalui pendekatan tersebut. Diantara budaya yang sampai saat ini masih menjadi tradisi di Kudus (khususnya wilayah sekitar menara) adalah larangan penyembelihan Lembu (sapi) hal ini dilakukan sebagai salah satu tanda menghormati masyarakat Budha-Hindu, karena lembu merupakan salah satu hewan yang di agungkan oleh pengikut keyakinan tersebut. Dalam Tulisan Solichin Salam,di sebutkan bahwa pada waktu itu Sunan Kudus pernah mengikat seekor lembu di sekitar pekarangan masjid, hal ini tentu menyita perhatian masyarakat yang masih memeluk agama hindu, alhasil masyarakat tersebut berbondong-bondong datang, sesudah hadir, maka sunan kudus kemudian bertabligh dengan politik tersebut, pada ahirnya banyak diantara mereka memeluk Islam. Sunan Kudus menyampaikan, bahwa semasa hidupnya Sunan Kudus melarang rakyatnya menyakiti atau memotong lembu, sebab pada suatu ketika sunan kudus pernah kehausan kemudian mendapatkan air susu dari seekor lembu.(4)

Cerita tersebut mengandung arti, bahwa mayoritas dari nenek moyang kita dahulu adalah pemeluk agama Hindu dan Budha, dengan demikian mereka sangat menghormati sapi, maka untuk tidak menyinggung perasaan dan kehormatan kepercayaan pemeluk agama tersebut, kemudian Sunan Kudus mengambil siasat dengan jalan membuat cerita yang mengandung filsafat seperti diatas, dengan demikian kita diajarkan untuk bertoleransi sebagaimana yang diajarkan Islam kepada kita.

\section{Bukti Arkeologis}

Arsitektur dari bangunan menara oleh Sunan Kudus merupakan sabuah bukti akulturasi budaya pada masa itu, hal ini telah di ungkap pada penelitian Nur Said, bahwa Mahakarya Menara Kudus tercermin nilai Estetika Lintas Budaya dan dalam bidang Sunan Kudus melakukan pendekatan Budaya (Kultural) dengan wajah toleran.(19)

Segala sesuatu pasti memiliki asal-usul adanya hal tersebut terjadi, asal-usul didirikannya Masjid Al-Aqsho dan Menara Kudus oleh Sunan Kudus di Kudus adalah sebagai salah satu dakwah untuk menyebarkan agama Islam. Sebenarnya sebelum didirikannya Masjid Al-Aqsho dan Menara Kudus di lokasi tersebut, Sunan Kudus Sebelumnya telah mendirikan sebuah masjid di Langger Dalem, jaraknya sekitar 200 meter dari letak masjid dan menara saat ini. Karena faktor tempat yang kurang 
strategis, yang jauh dari pusat keramaian maka letak masjid tersebut di pindah, seperti sekarang ini yang berada di tengah keramaian. Tujuannya seperti yang disebutkan sebelumnya, yaitu sebagai salah satu media dakwah, apabila tempat ibadah dekat dengan tempat keramaian tentu masyarakat akan mudah dalam melaksanakan ibadahnya.

\section{Bukti Tata Ruang Kudus Kulon}

Seperti yang kita ketahui tata letak Masjid Al-Aqsho bertetangga dengan salah satu Klenteng china, yaitu Klenteng Hok Ling Bio sehingga peneliti menanyakan kepada narasumber, yakni bapak Deni salah satu staff pengurus yayasan menara Kudus mengenai hubungan sosial, dan beliau menjelaskan bahwa letak tempat ibadah berbeda agama merupakan salah satu tempat pengujian iman, seperti kesabaran dan toleransi.

Sementara keadaan sosial kemasyarakatan di lingkungan Masjid AlAqsho dan Klenteng Hok Ling Bio dapat dikatakan harmoni, yaitu seimbang dan sikap toleransi beragama memang terjadi, terbukti tidak ada bentrokan yang mengatas namakan tempat ibadah. Akan tetapi di tahun 80-an, tepatnya tahun 1919 pernah terjadi keributan, dimana letak keributan tersebut terjadi di perempatan jalan raya Masjid Al-Aqsho, karena hal itu ada yang mengisukan keributan terjadi karena letak dua tempat ibadah yang berbeda kepercayaan, padahal sebenarnya bukan karena itu, akan tetapi karena faktor SI (Sarekat Islam), selain itu para pelaku kerusuhan berasal dari luar Kudus semua, jadi istilahnya pinjam tempat saja untuk melakukan kerusuhan tersebut.

Dari sejarah yang yang dilakukan sunan Kudus dapatkah hal tersebut di sebut toleransi beragama? Kata 'toleransi' bermakna sikap atau sifat toleran, secara harfiyah bermakna menghargai dan secara luas dapat diartikan sebagai prinsip sosial untuk bebas brpendapat, berlapang dada dalam prinsip yang dilakukan orang lain.(21) Toleransi merupakan sikap saling menghargai antar sesama, bahkan hal ini dapat dikatakan modal untuk melangsungkan kehidupan yang damai dan sejahtera. Hal tersebut terbukti bagaimana cara Sunan
Kudus melangsungkan kehidupan bermasyarakatnya dengan bermodal Toleransi beragama, hasil toleransi tersebut dapat menjadi salah satu jalan sebagai jalan untuk berdakwah. Konteks diatas, ternyata bukan sekadar pemikiran nonsense atau omong kosong belaka. Wujud toleransi beragama juga telah di terapkan oleh wali songo dalam menyebarkan agama Islam di Nusantara,(6) salah satunya adalah Syaikh Ja'far Shodiq atau lebih dikenal dengan Sunan Kudus seperti yang dipaparkan diatas.

\section{b. Peran Tali Akrab dalam Membumikan Toleransi}

Indonesia berdiri atas sokongan berbagai aliran beserta ideologi darimanapun, bahkan liberal sekalipun.(1) Sedangkan Islam di ibaratkan "Tokoh Historis" yang bersifat Omnipresent (Hadir dimana-mana) dalam setiap lini masa kehidupan manusia dan mengilhami siapa saja. Komunitas lintas agama di pantura atau yang sering disebut tali akrab merupakan sebuah komunitas yang dirintis oleh "R", dkk. Dalam wawancara yang peneliti lakukan, "R" menyatakan bahwa Dalam komunitas ini merupakan suatu perkumpulan umat dengan agama-agama yang berbeda baik yang legal maupun illegal. Diantaranya untuk agama yang legal adalah Islam, Kristen, Katolik, Hindu, Buddha, dan Konghucu. Untuk agama ilegal diantaranya adalah agama Baha'i, agama aliran Ahmadiyah. Selain itu terdapat pula kepercayaan Penghayat dan Sedulur Sikep atau Samin.

Pertanyaannya untuk apa komunitas lintas agama dan kepercayaan ini dibentuk? Pembentukan komunitas ini tak lain adalah untuk menyatukan perbedaan, sebab kita Indonesia, tentu kedamaian adalah dambaan. Selanjutnya dalam mewujudkan perdamaian, terdapat 5 etika hubungan sosial antar umat yakni; Al-Musyawwat artinya, kita memahami bahwa derajat manusia adalah sama. Al-Adalat artinya sikap anti diskriminasi. Al-Ta'asyusyi al-Silmi berarti eksistensi damai. Tasamuh yakni toleransi atau saling menghargai dan dialog arif, kostruktif serta transformatif.(14) Terbentuknya sebuah komunitas bertujuan untuk menjalin interaksi, komunikasi dan dialog termasuk komunitas lintas agama atau tali akrab. Berikut peran tali akrab dalam 
membumikan ajaran toleransi Sunan Kudus, diantaranya adalah sebagai berikut:

\section{Diskusi Interaktif}

Diskusi Interaktif merupakan diskusi yang dilakukan antara pemateri dan audiens atau antar audiens. Berikut diantaranya; Dialog lintas agama di balai budaya dengan tema Sunan Kudus dan sejarah Kota Kretek, mendialogkan Ahmadiyah di masjid Ahmadiyah semarang, disana kami membahas mengenai keberadaan, seluk beluk memgenai Aliran Ahmadiyah, Mendialogkan Agama Budha di Vihara Dammadipha Colo Kudus, dalam pertemuan tersebut kita membahas mengenai seluk beluk agama Budha, pendidikan, pemakaman juga perhatian dari pemerintah untuk keberadaan mereka. Dialog tentang sosialisasi antisipasi kebakaran dan dialog Sekte Advent, yang dilakukan di Rumah Makan How Jek. Dalam perkumpulan tersebut terdapat dialog interaktif dalam dua sesi, pada sesi pertama yakni dialog antisipasi kebakaran karena pada waktu tersebut sedang marak kebakaran, dialog ini diisi oleh anggota pemadam kebakaran, dialog interaktif bukan hanya dari kalangan Muslim, tetapi berbagai agama. Dialog interaktif kaum kristiani Sekte Advent, dalam dialog ini dapat dikatakan seperti halnya saling bercerita keluh kesah yang dialami dalam peribadatan, permasyarakatan dan sejarah agama yang mereka anut.

\section{Pagelaran Seni}

Pagelaran seni merupakan salah satu kegiatan dalam rangka mengenalkan kesenian yang dimilki antar agama dan kepercayaan, berikut diantanya; Pentas seni pada hari kenaikan Isa Al masih di Hotel Gripta Kudus, pada acara tersebut dihadiri oleh seluruh anggita lintas agama, minimal perwakilan dari agama dan kepercayaan. Di dalam acara tersebut kami menyaksikan pentas seni, berdoa bersama dan penggalangan amal untuk kaum kristiani, sedangkan yang tidak satu aliran dengan mereka hanya turut menghadiri dan menyaksikan, tanpa mengikuti yang mereka lakukan. Pentas seni dalam rangka perayaan acara halal bi halal, yang diadakan di GSJPDI Bukit Sion Kudus. Dimana peserta pada acara tersebut bukan hanya jemaat
Kristen, tetapi juga Penghayat, Samin, Muslim, Hindu, Budha, turut hadir dan beberapa ikut serta menampilkan karya seni, seperti permainan musik, paduan suara maupun tari dan di tempat tersebut masih dalam nuansa hari raya Idul Fitri. Acara tersebut ialah inisiatif komunitas lintas agama untuk melaksanakan halal bi halal tetapi bukan hanya kaum Muslim saja, tetapi lintas agama.

\section{Sambung Rasa Relasi Sosial}

Sambung rasa relasi sosial merupakan, kegiatas serupa dengan diskusi, yang di dalamnya diisi dengan saling sharing dan dialog mengenai keluh-kesah yang dialami, sehingga wadah ini selain dapat saling berbagi pengalaman dan masalah, juga turut serta mencari solusi terkait permasalahan yang dialami. Berikut diataranya; Kunjungan dari umat Baha'i di kediaman Bapak "R". Kehadiran mereka bukan sekedar kunjungan akan tetapi juga berdialog dengan Mahasiswa STAIN Kudus. Dialog antar umat beragama di Rutan Kudus.

Hingga sekarang toleransi memang masih berjalan. Lalu bagaimana peran dari komunitas lintas agama di pantura atau yang sering disebut tali akrab? Sebenarnya permasalahan utama tidak adanya toleransi adalah karena kurangnya komunikasi, dan posisi Tali Akrab sebenarnya tak lain adalah sebuah wadah yang menampung seluruh perbedaan untuk dapat berkumpul dan melakukan dialog, agar ada komunikasi dan kejelasan. Melalui komunitas tersebut, dalam analisis penulis, Tali Akrab merupakan penyambung tangan dari dakwah Sunan Kudus, dengan kita dapat berkumpul dengan berbagai agama pemikiran kita pasti akan lebih terbuka, kita akan lebih mengerti indahnya dapat hidup berdampingan di tengah perbedaan. Mulai dari dialog lintas agama, mendialogkan hal-hal yang bersifat umum hingga pada hal yang sangat vital seperti halnya isu-isu yang terjadi pada agama tersebut. Jika dulu dengan keberadaan Sunan Kudus dan kebijakan yang diberikan pada masyarakat pada waktu itu, maka saat ini perlu bagi kita menghidupkan lagi ruh dari ajaran yang Sunan Kudus berikan, salah satunya komunitas lintas agama di pantura atau tali akrab. 


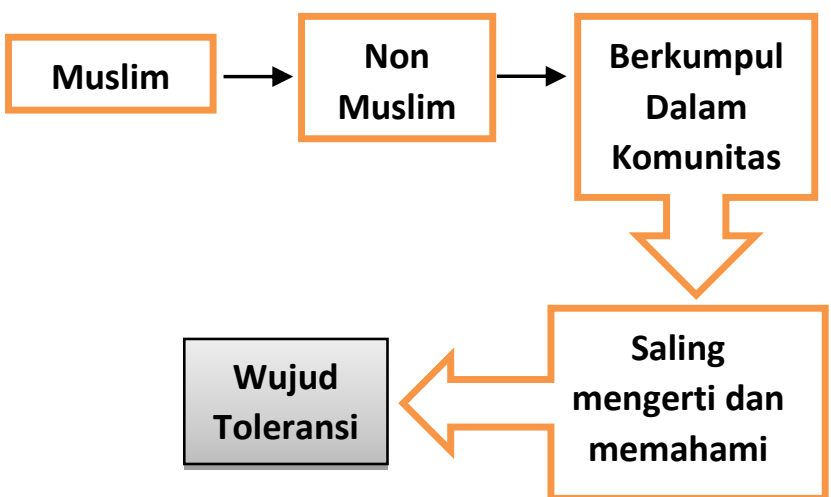

Gambar 1. Bagan toleransi dalam komunitas tali akrab.

Dengan langkah ini tentu kita akan mulai dapat bijak dalam melangkah, oleh karena itu, golongan millenial sebagai golongan yang masih produktif menjadi sasaran utama dengan beberapa sikap yang telah dijelaskan sebelumnya. Melalui generasi millenial inilah mindset dari masyarakat luas akan mengerti pentingnya hidup bertenggang rasa, dengan itu kedamaian akan terjadi, sikap tenggang rasa, hidup bermasyarakat di tengah perbedaan, khususnya dalam konteks agama, umat Islam dapat berdiri di tengah perbedaan, selanjutnya Moderasi Islam akan benar terjadi. Karena sadar atau tidak, sebenarnya golongan millenial inilah yang mudah mendapatkan hasud dalam hal baik maupun buruk, dapat kita lihat dari kasuskasus yang beredar, jarang sekali golongan tua (kelahiran 1960 - 1980) terlibat dalam kasus-kasus tindakan radikalisme. Seperti kasus yang pernah dimuat pada Koran Jawa Pos, bahwa terdapat pemuda yang menyerang umat gereja di Sleman dengan bersenjatakan Parang. Biksu Mulyanto di Tangerang tepatnya daerah Leguk juga mengalami nasib serupa saat melangsungkan ibadah. Kemudian di Situbondo Jawa Timur terjadi pula kerusuhan yang di akibatkan dari menghina Islam dan Kiai. Oleh karena itu generasi millennial merupakan tonggak utama dalam pembenahan dan pembangunan konsep pemikiran.

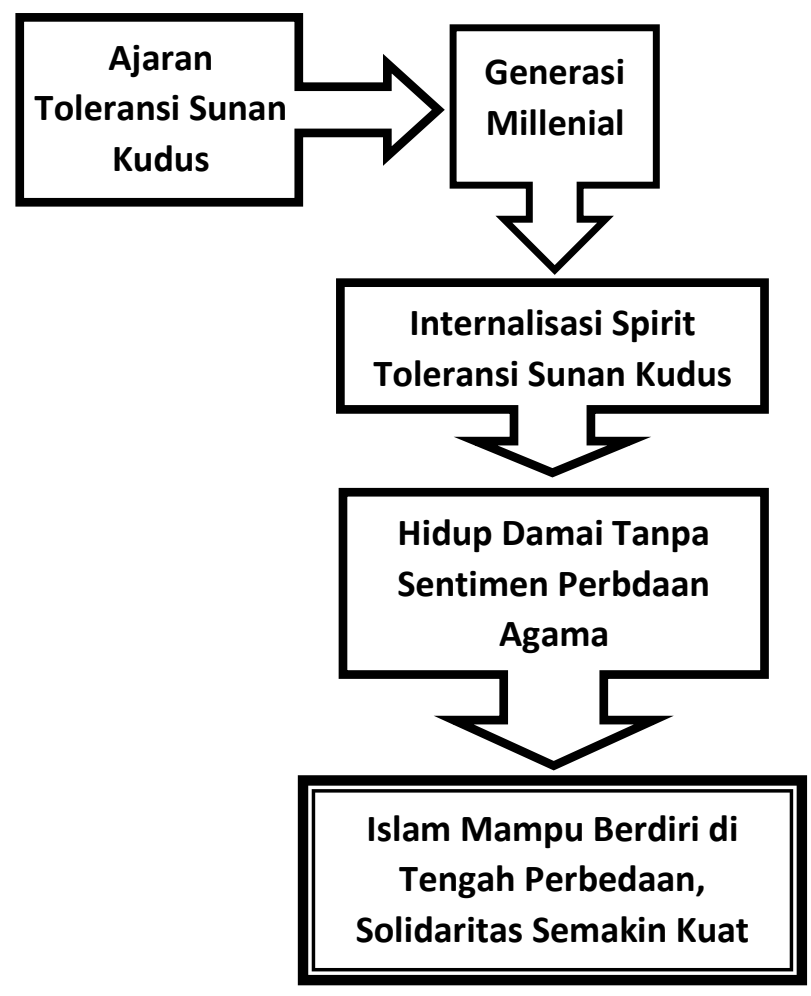

Gambar 2. Peta konsep dampak penelitian.

\section{Kesimpulan}

Dari pembahasan diatas, dapat kita simpulkan bahwa Wujud toleransi beragama juga telah di terapkan oleh wali songo dalam menyebarkan agama Islam di Nusantara salah satunya adalah Syaikh Ja'far Shodiq atau lebih dikenal dengan Sunan Kudus.

Meneladani sikap tenggang rasa Seperti yang di lakukan Sunan Kudus dalam melakukan toleransi beragama untuk hidup harmoni dengan beberapa jejak sejarah yang pernah Sunan Kudus lakukan. Selain itu telah kita ketahui pula bahwa permasalahan utama dari tidak ada sikap toleransi karena tidak adanya sesrawungan atau komunikasi didalamnya, maka perlu bagi kita dapat terlibat dalam wadah yang di dalamnya seluruh agama dapat berkumpul di dalamnya seperti halnya yang telah terlaksana pada Komunitas Lintas Agama di pantura, yakni Tali Akrab. Selain itu gerasi millenal merupakan salah satu stimulus tersendiri untuk dapat memberi pengaruh pada masyarakat lain, oleh karena itu, perlu kita kuatkan stimulus di dalamnya.

\section{Daftar Pustaka}

1. Achmad N. Pluralitas agama: kerukunan dalam keragaman. Kompas Media Nusantara, 2001. 
2. Fithrotul 'aini A, Mustaqim A. Dialektika Agama: Harmoni dalam Jemaat Ahmadiyah (Resepsi Jemaat Ahmadiyah Indonesia Manislor Kuningan Jawa Barat terhadap AyatAyat Jihad dan Perdamaian). FIKRAH 4: 243-260, 2017.

3. Hadi S. Metodologi Reaserch. Yogyakarta: Andi Offset, 1993.

4. Haidar A. Imam Ja'far Shadiq Dan Empat Mazhab Islam. Australia: Rafed Books, [date unknown].

5. Huda AN. Pendidikan Inklusif dari Pesantren [Online]. Idrak: Journal of Islamic Education 1, 2018. http://jurnal.stit-

rh.ac.id/index.php/idrak/article/view/11 [12 Oct. 2019].

6. Ma'rifah S, Mustaqim M. Pesantren Sebagai Habitus Peradaban Islam Indonesia. JURNAL PENELITIAN 9: 347-366, 2015.

7. Martin RC. Pendekatan kajian Islam dalam studi agama. Surakarta: Muhammadiyah University Press, 2001.

8. Moesa AM. Nasionalisme kiai: konstruksi sosial berbasis agama. IAIN Sunan Ampel Press, 2007.

9. Moleong. Metodologi Penelitian Kualitatif. Jakarta: Rosda Karya, 2001.

10. Mukhlis FH. Teologi Pancasila: Teologi Kerukunan Umat Beragama. FIKRAH 4: 171-186, 2016.

11. Mulia SM. Gempa Budaya Virtual. Semarang: Justisia, 2010.

12. Mustaqim M. Pendidikan Multikultural Perspektif Pendidikan Islam. Kudus: STAIN Kudus, 2007.
13. Mutiara KE. Menanamkan Toleransi Multi Agama sebagai Payung Anti Radikalisme: Studi Kasus Komunitas Lintas Agama dan Kepercayaan di Pantura Tali Akrab. FIKRAH 4: 293302, 2017.

14. Naim N. Teologi kerukunan: mencari titik temu dalam keragaman. Teras, 2011.

15. Naim N, Sauqi A. Pendidikan multikultural: konsep dan aplikasi. ArRuzz Media, 2008.

16. Nurina AI. Urgensi Studi Islam Interdisipliner di Era Milenial [Online]. https://www.academia.edu/ $[12$ Oct. 2019].

17. Rosyid M. Esai-Esai Toleransi. Yogyakarta: CV Idea Sejahtera, 2014.

18. Rosyid M. Local Wisdom Modal Toleransi: Studi Kasus di Kudus. FIKRAH 4: 276-292, 2017.

19. Said N. Gusjigang dan Kesinambungan Budaya Sunan Kudus: Relevansinya Bagi Pendidikan Islam Berbasis Local Genius. Jurnal Pendidikan Islam EMPIRIK 6, 2013.

20. Sarman. Pengantar Metodologi Penelitian Sosial. Lampung: Pustaka Fisip Unlam, 2004.

21. Yusuf AA. Wawasan Islam. Bandung: Pustaka Setia, 2002. 